\title{
Pelatihan Penyusunan Laporan Keuangan Sederhana Bagi Pelaku UMKM Di Desa Tegalarum Kecamatan Mranggen Kabupaten Demak
}

\author{
Saifudin1, Aprih Santoso², Sri Yuni Widowati \\ Universitas Semarang \\ Email : ªprihsantoso@usm.ac.id
}

\begin{abstract}
In order to increase the opportunities, capabilities and protection of SME actors, various policies have been established on the empowerment of SMEs which are carried out by fostering a business climate that supports the development of Micro, Small and Medium Enterprises and Development and fostering of Micro, Small and Medium Enterprises, Problems. what MSMEs players face in Tegalarum Village, Mranggen District, Demak Regency, are: (1) lack of knowledge about the preparation of financial reports. (2) There is no facility in the form of a training program that has been used yet. (3) There is no assistance for the preparation of financial reports. The purpose of PKM is to provide training to MSME players in Tegalarum Village, Mranggen District, Demak Regency so that they can find out about business developments and use financial reports to support the progress of their MSMEs. The results of PKM are the ability and skills to prepare financial reports by MSMEs actors in Tegalarum Village, Mranggen District, Demak Regency. The recommendation for the results of the implementation of PKM is to remember that compiling this financial report is a work that is continuous and sustainable, so it is better if the MSME actors in Tegalarum Village, Mranggen District, Demak Regency, do it regularly every time there is a transaction.
\end{abstract}

Keyword: Accounting, Reports, Skills, MSMEs

\section{Pendahuluan}

Sektor Usaha Mikro Kecil Menengah (UMKM) di Indonesia merupakan salah satu penopang ekonomi Indonesia selain sektor koperasi. Hal ini dapat terlihat dari bukti nyata bahwa sebagian besar UMKM di Indonesia menghadapi krisis di tengah-tengah pandemi Covid 19, ada yang masih eksis, akan tetapi ada pula yang tidak bisa eksis. Perkembangan jumlah UMKM dari tahun ke tahun semakin bertambah. Perkembangan UMKM baru terlihat dari sisi jumlahnya saja. Agar dapat meningkatkan kesempatan,

Pelatihan Penyusunan Laporan Keuangan Sederhana Bagi Pelaku UMKM 
kemampuan dan perlindungan terhadap para pelaku UKM, telah ditetapkan berbagai kebijakan tentang pemberdayaan UKM yang dilakukan dengan cara penumbuhan iklim usaha yang mendukung pengembangan Usaha Mikro, Kecil, dan Menengah dan Pengembangan dan pembinaan Usaha Mikro, Kecil, dan Menengah. ${ }^{1}$

Secara umum, khususnya dalam aspek finansial, hanya sedikit UMKM yang mengalami perkembangan dalam hal kinerja keuangannya. Hal ini tak lepas dari ketidaksadaran pelaku UMKM terhadap pentingnya pengelolaan keuangan perusahaan.Pengelolaan keuangan menjadi salah satu aspek penting bagi kemajuan perusahaan. Pengelolaan keuangan dapat dilakukan melalui akuntansi. Akuntansi merupakan proses sistematis untuk menghasilkan informasi keuangan yang dapat digunakan untuk pengambilan keputusan bagi penggunanya.

Sepanjang UMKM masih menggunakan uang sebagai alat tukarnya, akuntansi sangat dibutuhkan oleh UMKM. Akuntansi akan memberikan beberapa manfaat bagi pelaku UMKM, antara lain: (1) UMKM dapat mengetahui kinerja keuangan perusahaan, (2) UMKM dapat mengetahui, memilah, dan membedakan harta perusahaan dan harta pemilik, (3) UMKM dapat mengetahui posisi dana baik sumber maupun penggunaannya, (4) UMKM dapat membuat anggaran yang tepat, (5) UMKM dapat menghitung pajak, dan (6) UMKM dapat mengetahui aliran uang tunai selama periode tertentu. Bisnis yang baik tentunya harus diiringi dengan pembukuan finansial yang memadai agar pengeluaran dan pemasukan usaha dapat dimonitor secara akurat. ${ }^{2}$

1Desmintari., Husnah. N.L. \& Ayunita. A.S. Pemberdayaan Masyarakat Melalui Pelatihan Manajemen dan Pembukuan Akuntansi Sederhana bagi Pelaku UKM Pertanian di Depok. Prosiding Seminar Hasil Pengabdian kepada Masyarakat. 1(1). (2018). 1-5.

${ }^{2}$ Nurmala, P., Hidayati, WN., Adiwibowo, AS., Nazar, SN., Purnomo, LI., \& Anis Syamsu Rizal, AS. (2020). Pemberdayaan Masyarakat Melalui Pembuatan Laporan Keuangan Sederhana Keluarga Pada Ibu-ibu PKK Citra Villa. L O Y A L I T A S : Jurnal Pengabdian Kepada Masyarakat. III(2), (2020), 198-208. 
Melihat manfaat yang dihasilkan akuntansi, pelaku UMKM seharusnya sadar bahwa akuntansi penting bagi perusahaan mereka. Penggunaan akuntansi dapat mendukung kemajuan UMKM khususnya dalam hal keuangan. Peningkatan laba juga dapat direncanakan dengan menggunakan akuntansi. Dengan tingkat laba yang semakin meningkat, perkembangan UMKM akan menjadi lebih baik sehingga UMKM akan benar-benar menjadi salah satu solusi bagi masalah perekonomian di Indonesia. Namun, masih banyak UMKM yang belum menggunakan akuntansi dalam menunjang kegiatan bisnisnya.

Alasan pelaku UMKM tidak menggunakan akuntansi antara lain adalah akuntansi dianggap sesuatu yang sulit dantidak penting. Beberapa pelaku UMKM mengatakan bahwa tanpa akuntansi pun perusahaan tetap berjalan lancar dan selalu memperoleh laba. Banyak pelaku UMKM merasa bahwa perusahaan mereka berjalan normal namun sebenarnya UMKM tersebut tidak mengalami perkembangan. Ketika mereka mendapatkan pertanyaan mengenai laba yang didapatkan setiap periode, mereka tidak bisa menunjukkan dengan nominal angka melainkan dengan aset berujud seperti tanah, rumah, atau kendaraan. Lebih lanjut, aset tersebut didapatkan tidak hanya dengan dana perusahaan tetapi terkadang ditambah dengan harta pribadi. Aset tersebut terkadang juga bukan digunakan untuk perusahaan namun digunakan untuk kepentingan pribadi dan tidak terdapat pencatatan ataupun pemisahan di antara keduanya. Hal ini menyebabkan perkembangan perusahaan khususnya dalam hal kinerja keuangan tidak dapat diketahui secara jelas.

Pelaku UMKM merasa kesulitan jika harus menggunakan akuntansi dalam kegiatan bisnisnya. Hal ini dikarenakan tidak adanya pedoman atau buku yang dapat dijadikan referensi untuk belajar mengelola keuangan UMKM. Buku-buku yang beredar saat ini memang belum ada yang fokus pada pengelolaan keuangan UMKM. Terdapat beberapa judul buku Akuntansi untuk UMKM, namun melihat isinya sama seperti buku akuntansi 
untuk perusahaan besar. Banyak transaksi yang terjadi di UMKM seperti barter/ tukar jasa namun tidak diberikan contoh dalam buku sehingga ketika transaksi tersebut terjadi, pelaku UMKM lebih memilih untuk tidak mencatatnya. Apabila terdapat banyak transaksi serupa dan tidak dicatat tentunya akan membawa dampak negatif bagi kinerja keuangan perusahaan. Selain belum ada buku yang secara spesifik membahas transaksi dalam UMKM, banyak pelaku UMKM yang enggan membaca buku. Pengelolaan keuangan menjadi salah satu masalah yang seringkali terabaikan oleh para pelaku bisnis UMKM. ${ }^{3}$

Hal ini juga dialami pelaku UMKM Di Desa Tegalarum Kecamatan Mranggen Kabupaten Demak sebagai mitra PKM dari Tim PKM FE Universitas Semarang kami dengan masalah yang dihadapinya, berupa : (1) kurangnya pengetahuan tentang penyusunan laporan keuangan. (2) Belum ada sarana berupa program pelatihan yang sudah digunakan. (3) Belum ada pendampingan untuk penyusunan pelaporan keuangan. Atas dasar analisis situasi yang telah dilakukan dan kebutuhannya serta hasil diskusi dengan mitra PKM tersebut seta memperhatikan kemampuan Tim PKM FE Universitas Semarang, maka masalah yang diprioritaskan akan ditangani melalui kegiatan pelatihan ini adalah pelatihan penyusunan laporan keaungan sederhana bagi UMKM.

Laporan Keuangan sederhana yang disesuaikan dengan keadaan di UMKM tersbut namun tidak menyimpang dari standar dan peraturan yang ada. Tujuan pelatihan ini adalah agar pelaku UMKM Di Desa Tegalarum Kecamatan Mranggen Kabupaten Demak dapat mengetahui perkembangan usaha dan memanfaatkan Laporan keuangan guna mendukung kemajuan UMKM mereka.

3Dawam, Aulia. Pendampingan Penyusunan Laporan Keuangan Sesuai Standar Akuntansi Berbasis Etap Di Umkm Batik Tanjung Bumi Kabupaten Bangkalan. J-ADIMAS (Jurnal Pengabdian kepada Masyarakat). 6(2), (2018), 74- 78 


\section{Metode}

1. Tahapan Kegiatan

Tahapan kegiatan dalam pelaksanaaan pengabdian kepada masyarakat dapat terlihat dari bagan di bawah ini:

1) PERSIAPAN:

Pra Survei: Permasalahan dan Kebutuhan Mitra

Identifikasi Permasalahan

1. Kurangnya pengetahuan tentang pelaporan keuangan.

2. Belum ada sarana dan prasarana berupa program yang mudah digunakan.

3. Belum ada pendampingan untuk penyusunan pelaporan keuangan.

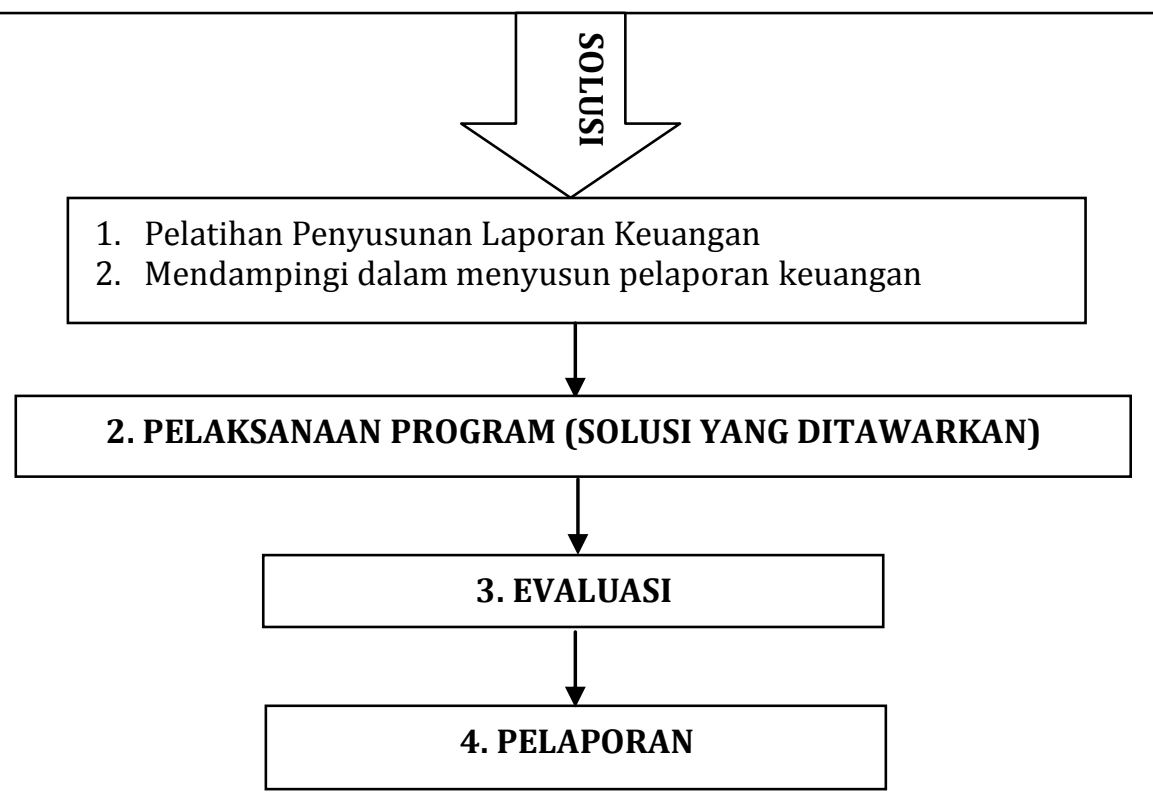

Gambar 1. Tahapan Kegiatan

(Sumber: Dokumentasi Kegiatan, 2020)

Adapun prosedur kerja yang dilaksanakan oleh pengabdian adalah:

a. Persiapan

Tahap persiapan merupakan tahap awal sebelum pelaksanaan kegiatan. Dalam tahap ini ada beberapa hal yang dilakukan, yaitu:

1) Pra Survei: Identifikasi Permasalahan dan Kebutuhan Mitra. 
2) Pembentukan Tim: Pembentukan Tim untuk memberikan solusi bagi permasalahan dan kendala yang dihadapi oleh mitra. Tim terdiri dari berbagai kompetensi yang dipadukan untuk memberikan solusi pemecahan masalah mitra.

3) Pembuatan Proposal: pembuatan proposal yang menawarkan solusi untuk permasalahan dan kebutuhan mitra.

4) Koordinasi antara Tim dengan Mitra: Untuk merencanakan pelaksanaan secara konseptual, operasional, serta job description masing-masing Tim dan Mitra

b. Pelaksanaan

Bekerjasama dengan Pemerintah Desa Tegalarum untuk melaksanakan pengabdian. Pelaksanaan kegiatan dilakukan di lingkungan Balai Rakyat Desa Tegalarum Mranggen Kabupaten Demak. Pelaksanaan pengabdian terdiri dari 2 kegiatan yaitu pelatihan penyusunan pelaporan keuangan sederhana dan pendampingan penyusunan pelaporan keuangan. Berdasarkan teori bahwa semua transaksi yang dilakukan dengan pihak lain harus dilakukan pencatatan, sebagai pertanggungjawaban. ${ }^{4}$

c. Evaluasi

Evaluasi program dilaksanakan dengan membandingkan keadaan mitra sebelum dan sesudah program dilaksanakan. Keberhasilan program ditujukan dengan adanya perubahan yang positif dari keadaan mitra yaitu peningkatan pengetahuan tentang penyusunan pelaporan, dan peningkatan ketrampilan dan kemampuan dalam menyusun pelaporan.

d. Pelaporan: Pembuatan laporan pelaksanaan kegiatan

${ }^{4}$ IMM, Nur Suci \& Ekaningtias, Diah, Penyuluhan Akuntansi Dan Pemberdayaan Masyarakat Dalam Mewujudkan Kawasan Yang Asri Di Gunung Anyar Asri Surabaya. Seminar Nasional Hasil Pengabdian Kepada Masyarakat, [S.l.], 2(1), (2018), 339-344 


\section{Metode Pendekatan}

Metode pendekatan yang digunakan dalam mencapai tujuan adalah pendekatan participatory training, yaitu pendekatan yang menekankan pada partisipasi penuh dari mitra dan pendampingan dalam mencapai tujuan. Pendekatan participatory training dilakukan melalui beberapa langkah pembelajaran dalam bentuk pelatihan dan pendampingan. Pelatihan sebagai proses mengajar keterampilan yang dibutuhkan orang baru untuk melakukan pekerjaannya. ${ }^{5}$

3. Partisipasi Mitra

Komitmen dari pelaku usaha memiliki peranan penting dalam menjaga kelangsungan hidup usaha (Maulani et al, 2020). Mitra program yaitu Pemerintah Desa Tegalarum Mranggen Demak beserta masyarakat pelaku UMKM Desa Tegalarum. Sebagai obyek, yang akan ditangani permasalahannya melalui peningkatan pengetahuan tentang pelaporan keuangan, dan pendampingan penyusunan pelaporan keuangan. Sebagai subyek yaitu mitra berperan aktif dalam kegiatan atau program-program solusi yang diberikan oleh tim pengabdian. Selanjutnya mitra PKM akan dilibatkan dalam merencanakan program, penjadwalan kegiatan, ikut serta dalam pelatihan sampai pada evaluasi program.

4. Evaluasi

Tabel 1. Evaluasi Program

\begin{tabular}{|l|l|l|l|}
\hline \multicolumn{1}{|c|}{ Program } & \multicolumn{1}{|c|}{ Indikator } & \multicolumn{1}{c|}{ Kriteria } & \multicolumn{1}{c|}{ Instrumen } \\
\hline $\begin{array}{l}\text { Penyuluhan } \\
\text { Penyusunan } \\
\text { pelaporan keuangan } \\
\text { sederhana }\end{array}$ & $\begin{array}{l}\text { Pemahaman } \\
\text { peserta tentang } \\
\text { menyusun } \\
\text { pelaporan }\end{array}$ & $\begin{array}{l}\text { Peningkatan } \\
\text { Pengetahuan } \\
\text { penyusunan pelaporan }\end{array}$ & $\begin{array}{l}\text { Pedoman } \\
\text { wawancara } \\
\text { dan } \\
\text { observasi }\end{array}$ \\
\hline $\begin{array}{l}\text { Pendampingan dalam } \\
\text { menyusun pelaporan }\end{array}$ & $\begin{array}{l}\text { Ketrampilan dan } \\
\text { ketepatan dalam } \\
\text { menyusun }\end{array}$ & $\begin{array}{l}\text { Peningkatan } \\
\text { ketrampilan dan } \\
\text { ketepatan dalam }\end{array}$ & $\begin{array}{l}\text { Pedoman } \\
\text { wawancara } \\
\text { dan } \\
\text { observasi }\end{array}$ \\
\hline
\end{tabular}

\section{Sumber: Dokumentasi Kegiatan, 2020}

${ }^{5}$ Dessler, Gary, (2011). Manajemen Sumber Daya Manusia, Jilid 1 Edisi 10. Penerbit PT Indeks, Jakarta 


\section{Hasil dan Diskusi}

Kegiatan yang telah dilakukan dalam pengabdian ini sebagai berikut:

1. Melaksanakan Rapat Koordinasi Persiapan Kegiatan Pengabdian dan Pembagian Tugas. Adapun pembagian tugas dari Tim Pengabdian adalah sebagai berikut:

Tabel 2. Pembagian Tugas Tim Pengabdian

\begin{tabular}{|l|l|}
\hline \multicolumn{1}{|c|}{ Materi } & \multicolumn{1}{c|}{ Pelaksana } \\
\hline Pelatihan & Tim Pelaksana \\
\hline Pendampingan & Tim Pelaksana \\
\hline
\end{tabular}

Sumber: Dokumentasi Kegiatan, 2020

2. Koordinasi Pertemuan dengan obyek atau Mitra.

Koordinasi dengan mitra ini kami membicarakan mengenai hal-hal yang berhubungan dengan penyusunan pelaporan. Aktivitas pembukuan semisal aktivitas memulai usaha (investasi awal), transaksi pembelian bahan baku, pemasukan/ penerimaan, pembelanjaan /pengeluaran, penjualan secara kredit, menerima pembayaran piutang penjualan, dan seterusnya. 6 Dalam menyusun pelaporan ini kita perlukan suatu program akuntansi sederhana dan perlu petugas yang melakukan pembuatan pelaporan. Kami juga menjelaskan mengenai langkah-langkah yang perlu dilakukan dalam penyusunan pelaporan.

3. Koordinasi pengisian pelaporan yang akan kami gunakan untuk menyusun laporan keuangan sederhana, sebagai berikut :

${ }^{6}$ Muljanto, Muhammad Agus, Pencatatan dan Pembukuan Via Aplikasi Akuntansi UMKM di Sidoarjo. Jurnal Ilmiah Pangabdhi. 6(1), (2020), 40-43. 
Tabel 3. Laporan Keuangan Sederhana

\begin{tabular}{|c|c|c|c|c|}
\hline \multirow{2}{*}{ Akun } & \multicolumn{4}{|c|}{ Saldo } \\
\hline & & Debit & & Kredit \\
\hline Kas & $\mathrm{Rp}$ & 53.000 .000 & & \\
\hline Peralatan & $\mathrm{Rp}$ & 10.000 .000 & & \\
\hline Modal disetor & & & $\mathrm{Rp}$ & 50.000 .000 \\
\hline Utang Usaha & & & $\mathrm{Rp}$ & 5.000 .000 \\
\hline Beban gaji & $\mathrm{Rp}$ & 2.000 .000 & & \\
\hline Pendapatan & & & $\mathrm{Rp}$ & 10.000 .000 \\
\hline & Rp & 65.000 .000 & $\mathrm{Rp}$ & 65.000 .000 \\
\hline
\end{tabular}

Sumber: Dokumentasi Kegiatan, 2020

4. Pelatihan penyusunan laporan yang telah bisa untuk digunakan.

Pengelolaan keuangan dapat dilakukan melalui akuntansi. ${ }^{7}$ Salah satu ciri UKM adalah mereka tidak memisahkan transaksi pribadi dengan transaksi perusahaan. ${ }^{8}$ Setelah penyusunan program laporan keuangan sederhana selesai diadakan pelatihan tentang penyusunan laporan keuangan dengan program akuntansi sederhana. Dalam pelatihan tersebut kami jelaskan mengenai pengertian laporan keuangan, tujuan menyusun laporan keuangan serta langkah-langkah menyusun laporan keuangan.

${ }^{7}$ Noor, Aris Setia \& Lestari, Berta. (2018). Penyuluhan Pelatihan Akuntansi Pencatatan Keuangan Di Kecamatan Mandastana Kabupaten Barito Kuala Kalimantan Selatan.

${ }^{8}$ Shochih, Moh. Perancangan Sistem Akuntansi pada Industri Kecil. Jurnal Pendidikan Akuntansi Indonesia. VI(1), (2008). 98-109 

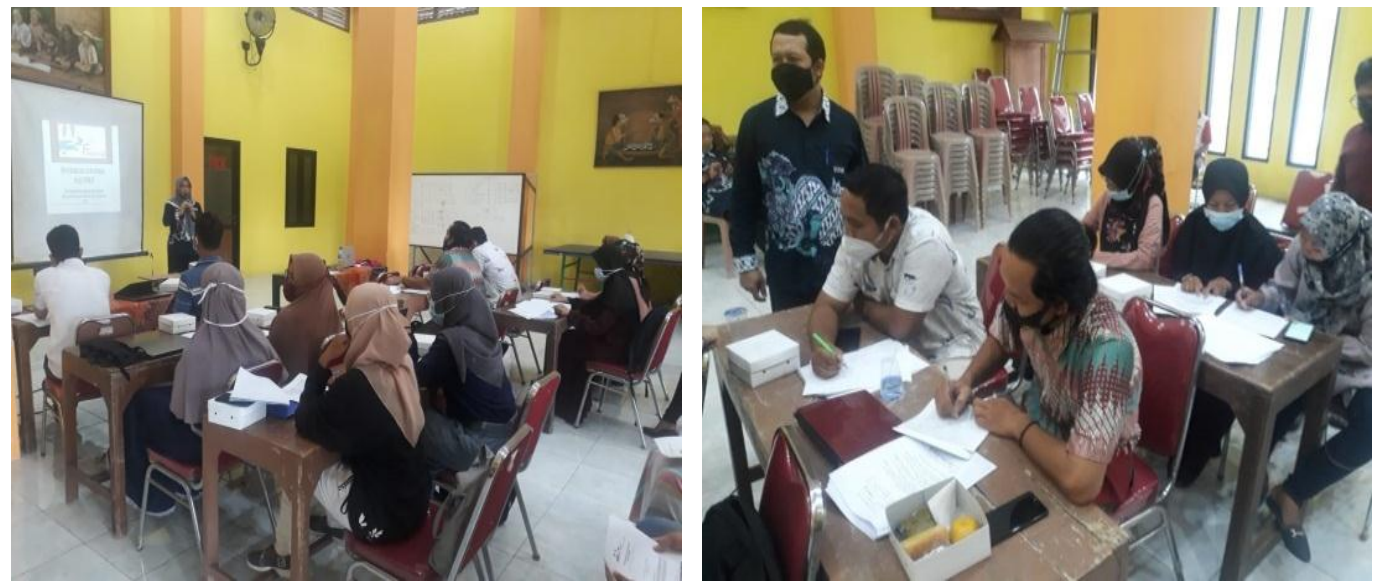

Gambar 2. Pelaksanaan Pelatihan (Sumber: Dokumentasi Kegiatan, 2020)

5. Pendampingan penggunaan aplikasi.

Setelah diadakan pelatihan tentang penyusunan laporan keuangan kita lanjutkan dengan pendampingan penyusunan laporan keuangan.

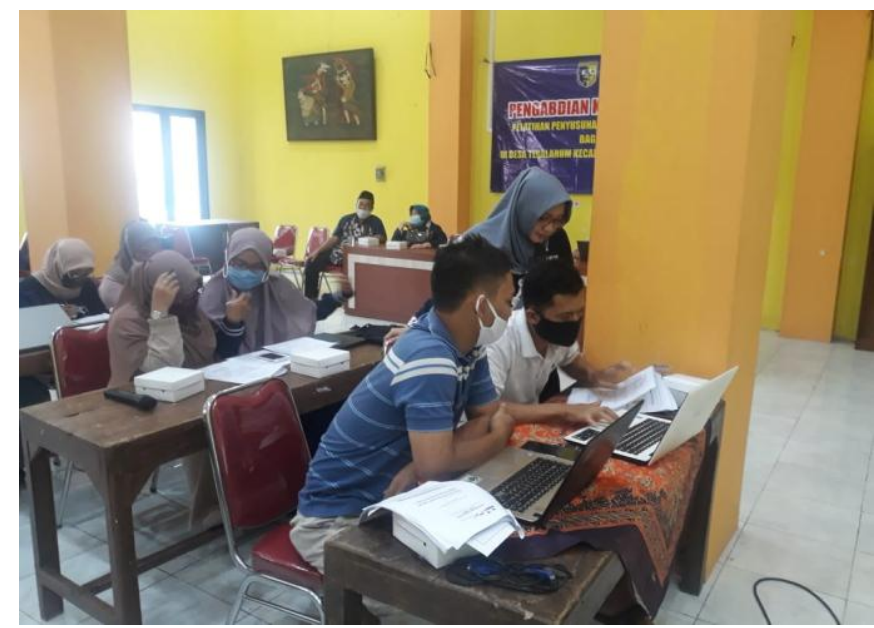

Gambar 3. Proses Simulasi (Sumber: Dokumentasi Kegiatan, 2020)

6. Evaluasi Kegiatan Pengabdian Kepada Masyarakat

Kegiatan pengabdian kepada masyarakat untuk penyusunan laporan keuangan pada pelaku UMKM telah berjalan dengan lancar yang meliputi 
pelatihan cara menyusun pelaporan dan pendampingan penyusunan pelaporan keuangan. Kegiatan pengabdian kepada masyarakat ini diikuti oleh pelaku UMKM desa Tegalarum Mranggen Demak.

[

Tabel 4. Hasil PKM

\begin{tabular}{|l|l|}
\hline \multicolumn{1}{|c|}{ Program PKM } & \multicolumn{1}{c|}{ Hasil Wawancara } \\
\hline $\begin{array}{l}\text { Pelatihan Penyusunan pelaporan } \\
\text { keuangan. }\end{array}$ & $\begin{array}{l}\text { Ada Peningkatan Pengetahuan } \\
\text { penyusunan pelaporan } \\
\text { keuangan. }\end{array}$ \\
\hline $\begin{array}{l}\text { Pendampingan dalam menyusun } \\
\text { pelaporan }\end{array}$ & $\begin{array}{l}\text { Mampu Peningkatan } \\
\text { ketrampilan dan ketepatan } \\
\text { dalam menyusun pelaporan } \\
\text { keuangan }\end{array}$ \\
\hline
\end{tabular}

Sumber: Dokumentasi Kegiatan, 2020.

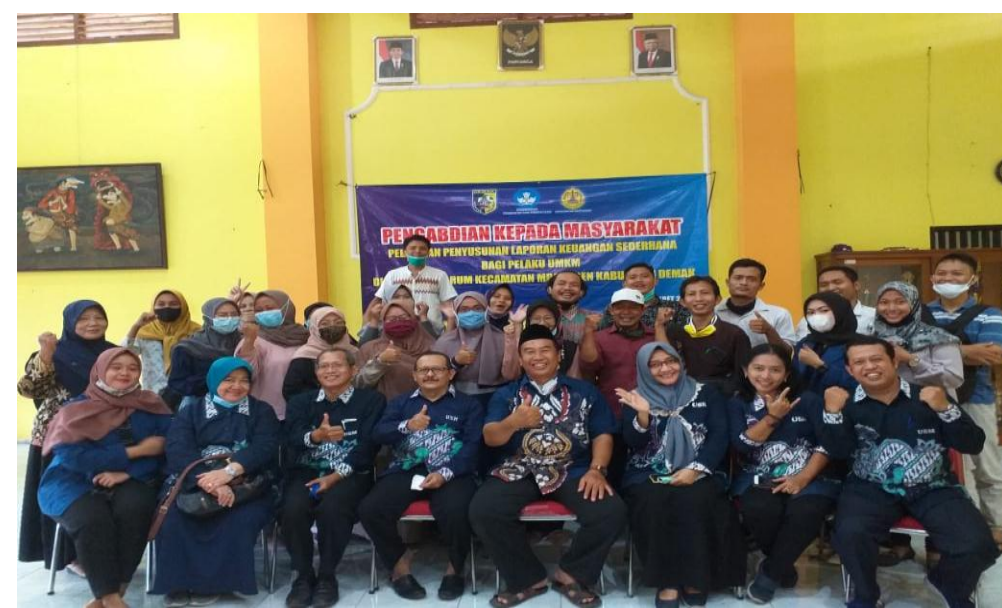

\section{Gambar 4. Tim PKM FE Universitas Semarang beserta Kepala Desa dan Peserta Pelatihan (Sumber: Dokumentasi Kegiatan, 2020)}

Laporan keuangan yang diperlukan untuk usaha kecil lebih sederhana dari laporan keuangan perusahaan besar. ${ }^{9}$ Pada sesi penyuluhan penyusunan laporan keuangan yang fokus pada pembahasan cara menyusun laporan keuangan yang akuntabel dan berdasarkan suatu standar akuntansi

${ }^{9}$ Hairunisya, Nani \& Subiyantoro, Hari. Pelatihan Dan Pendampingan Pembuatan Laporan Keuangan Kepada Pengusaha UMKM Di Kecamatan Karangrejo Kabupaten Tulungagung. J-ADIMAS (Jurnal Pengabdian kepada Masyarakat). 5(1), (2017), 34-45 
keuangan. Hal ini sangat ditanggapi positif oleh peserta yang akan melakukan penyusunan laporan keuangan. Selain pengetahuan tentang penyusunan laporan keuangan juga perlu dilengkapi dengan program akuntansi sederhana yang bisa mempercepat dan memudahkan dalam penyusunan laporan keuangan. Untuk meningkatkan ketrampilan dan ketepatan dalam menyusun laporan keuangan diperlukan pendampingan untuk memasukan data keuangan ke dalam program akuntansi sampai keluar laporan keuangan. Kesimpulan pada hasil evaluasi akhir kegiatan pengabdian masyarakat ini adalah kemampuan meningkatkan pengetahuan dan kemapuan serta ketrampilan penyusunan laporan keuangan yang dapat kami sampaikan sesuai dengan tabel hasil wawancara kami dengan peserta.

\section{Simpulan}

Pelaksanaan pelatihan tentang pelatihan cara menyusun laporan keuangan yang akuntabel dan sesuai dengan standar akuntansi keuangan mampu meningkatkan pengetahuan peserta dalam menyusun laporan keuangan. Dengan adanya pendampingan dalam menyusun laporan keuangan mampu meningkatkan ketrampilan dan ketepatan dalam menyusun laporan keuangan. Mengingat menyusun laporan keuangan ini merupakan suatu pekerjaan yang secara terus menerus dan berkesinambungan maka sebaiknya dalam mengerjakan dilakukan secara rutin setiap ada transaksi sesegera mungkin dimasukan dalam program akuntansi yang sudah tersedia. Hal ini untuk menghindari penunpukan pekerjaan dan juga agar pelaporan dapat disajikan tepat waktu. 


\section{Daftar Referensi}

Dawam, Aulia. (2018). Pendampingan Penyusunan Laporan Keuangan Sesuai Standar Akuntansi Berbasis Etap Di Umkm Batik Tanjung Bumi Kabupaten Bangkalan. J-ADIMAS Uurnal Pengabdian kepada $\begin{array}{lll}\text { Masyarakat). } & 6(2), & 74-\end{array}$ https://jurnal.stkippgritulungagung.ac.id/index.php/jadimas/article/vi ew/885

Desmintari., Husnah. N.L. \& Ayunita. A.S. (2018). Pemberdayaan Masyarakat Melalui Pelatihan Manajemen dan Pembukuan Akuntansi Sederhana bagi Pelaku UKM Pertanian di Depok. Prosiding Seminar Hasil $\begin{array}{llll}\text { Pengabdian kepada } & \text { Masyarakat. 1(1). } & 1-5 .\end{array}$ https://conference.upnvj.ac.id/index.php/pkm/article/view/98

Dessler, Gary, (2011). Manajemen Sumber Daya Manusia, Jilid 1 Edisi 10. Penerbit PT Indeks, Jakarta

Hairunisya, Nani \& Subiyantoro, Hari. (2017). Pelatihan Dan Pendampingan Pembuatan Laporan Keuangan Kepada Pengusaha UMKM Di Kecamatan Karangrejo Kabupaten Tulungagung. J-ADIMAS Uurnal Pengabdian kepada Masyarakat). 5(1), 34-45. DOI : 10.29100/j-adimas.v5i2.627. https://jurnal.stkippgritulungagung.ac.id/index.php/jadimas/article/vi ew/627

IMM, Nur Suci \& Ekaningtias, Diah. (2018). Penyuluhan Akuntansi Dan Pemberdayaan Masyarakat Dalam Mewujudkan Kawasan Yang Asri Di Gunung Anyar Asri Surabaya. Seminar Nasional Hasil Pengabdian Kepada Masyarakat, [S.l.], 2(1), 339-344. http://senias.uim.ac.id/index.php/senias_2017/article/view/194

Maulani, Terra.S., Dialysa, Fia., Prawirasasra, \& Kannya. P. (2016). Pelatihan Pembukuan Keuangan Sederhana dan Motivasi Kewirausahaan pada Kelompok Usaha Makanan Keluarahan Neglasari Kecamatan Cibeunying Kaler Bandung. Jurnal Dharma Bhakti STIE Ekuitas. 1(1). 5460. http://repository.ekuitas.ac.id/handle/123456789/207

Muljanto, Muhammad Agus. (2020). Pencatatan dan Pembukuan Via Aplikasi Akuntansi UMKM di Sidoarjo. Jurnal Ilmiah Pangabdhi. 6(1), 40-43.

DOI:https://doi.org/10.21107/pangabdhi.v6i1.6926. http://journal.trunojoyo.ac.id/pangabdhi ISSN: 2477-6

Noor, Aris Setia \& Lestari, Berta. (2018). Penyuluhan Pelatihan Akuntansi Pencatatan Keuangan Di Kecamatan Mandastana Kabupaten Barito Kuala Kalimantan Selatan. Jurnal Pengabdian Siliwangi. 4(1), 68-71. http://jurnal.unsil.ac.id/index.php/jps/article/view/421 
Nurmala, P., Hidayati, WN., Adiwibowo, AS., Nazar, SN., Purnomo, LI., \& Anis Syamsu Rizal, AS. (2020). Pemberdayaan Masyarakat Melalui Pembuatan Laporan Keuangan Sederhana Keluarga Pada Ibu-ibu PKK Citra Villa. L O Y A L I T A S : Jurnal Pengabdian Kepada Masyarakat. III(2), 198-208 DOI: https://doi.org/10.30739/loyal.v3i2.389 http://ejournal.iaida.ac.id/index.php/loyal/article/view/389

Shochih, Moh. (2008). Perancangan Sistem Akuntansi pada Industri Kecil. Jurnal Pendidikan Akuntansi Indonesia. VI(1), 98-109. https://journal.uny.ac.id/index.php/jpakun/article/view/1794

Widodo, Agus. (2014). Akuntansi Organisasi Nirlab. 21 Juli 2017/https://aguswidodo03.files.wordpress.com/2014/09/akuntansi -organisasi- nirlaba.pdf. 